
Available to the public from:

U.S. Department of Commerce

National Technical Information Service

5285 Port Royal Road

Springfield, VA, 22161-0002

(703) 487-4650

Available electronically at http://www.doe.gov/bridge. Available to U.S. Department of Energy and its contractors in paper from:

U.S. Department of Energy

Office of Scientific and Technical Information

P.O. Box 62

Oak Ridge, TN, 37831-0062

(423) 576-8401

Reference herein to any specific commercial product, process, or service by trade name, trademark, manufacturer, or otherwise, does not necessarily constitute or imply its endorsement, recommendation, or favoring by the U.S. Government or any agency thereof or its contractors or subcontractors. 


\section{CORRECTIVE ACTION PLAN FOR CORRECTIVE ACTION UNIT 427: AREA 3 SEPTIC WASTE SYSTEMS 2 AND 6 TONOPAH TEST RANGE, NEVADA}

Controlled Copy No.:

Revision: 0

October 1998

Prepared for the

U. S. Department of Energy

Nevada Operations Office

Work Performed Under Contract No. DE-AC08-96NV11718 


\section{CORRECTIVE ACTION PLAN FOR CORRECTIVE ACTION UNIT 427: AREA 3 SEPTIC WASTE SYSTEMS 2 AND 6 TONOPAH TEST RANGE, NEVADA}

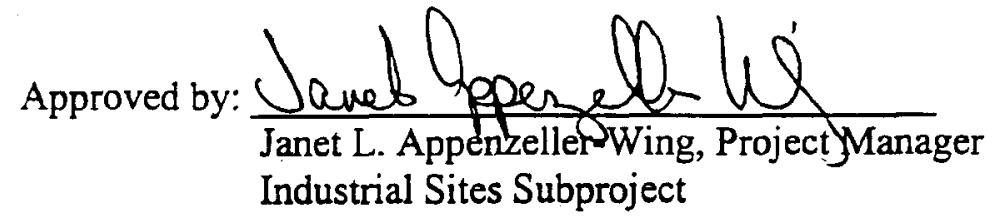

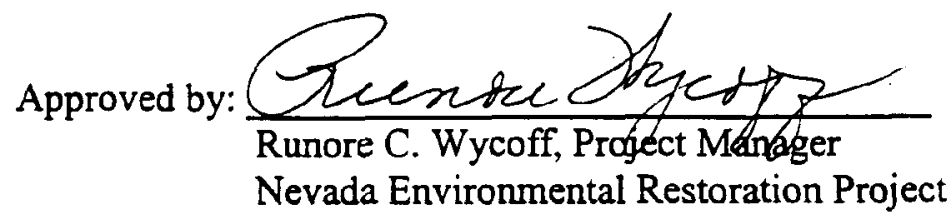

Date: $11 / 3 / 98$

Date: $11 / 3 / 58$ 
FIGURES $\ldots \ldots \ldots \ldots \ldots \ldots \ldots \ldots \ldots \ldots \ldots \ldots \ldots \ldots \ldots \ldots \ldots \ldots \ldots$ ACRONYMS AND ABBREVIATIONS $\ldots \ldots \ldots \ldots \ldots \ldots \ldots \ldots \ldots \ldots \ldots$ vii

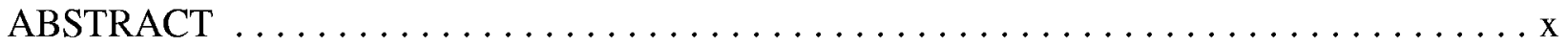

1.0 INTRODUCTION $\ldots \ldots \ldots \ldots \ldots \ldots \ldots \ldots \ldots \ldots \ldots \ldots \ldots \ldots \ldots \ldots$

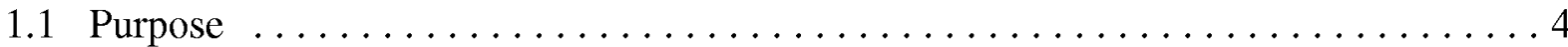

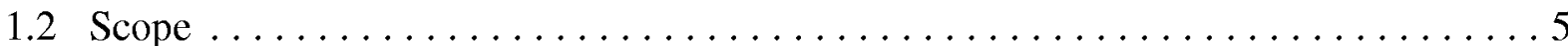

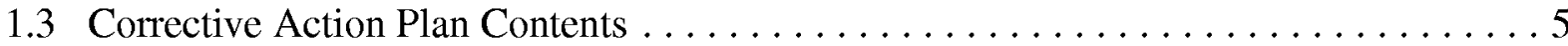

2.0 DETAILED STATEMENT OF WORK $\ldots \ldots \ldots \ldots \ldots \ldots \ldots \ldots \ldots \ldots \ldots$

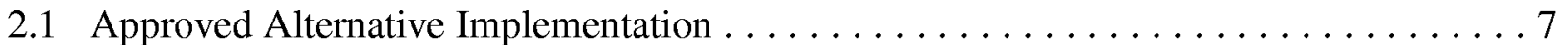

2.1.1 Removal of Septage from Septic Tank 33-5 . . . . . . . . . . . . . . . . 7

2.1.2 Closure In-Place of Septic Tank $33-5 \ldots \ldots \ldots \ldots \ldots \ldots \ldots$

2.1.3 Administrative Controls - Posting of Warning Signs $\ldots \ldots \ldots \ldots \ldots \ldots \ldots$

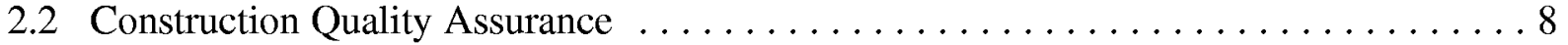

2.3 Waste Management $\ldots \ldots \ldots \ldots \ldots \ldots \ldots \ldots \ldots \ldots \ldots$

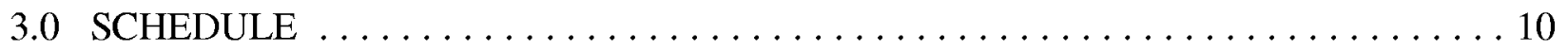

4.0 POST-CLOSURE MONITORING PLAN $\ldots \ldots \ldots \ldots \ldots \ldots \ldots \ldots \ldots \ldots$

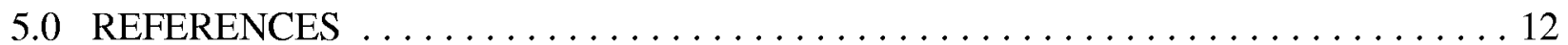

\section{APPENDICES}

APPENDIX A - PROJECT ORGANIZATION

APPENDIX B - DISTRIBUTION LIST 


\section{TABLE OF CONTENTS (continued)}

\section{FIGURES}

FIGURE 1 - LOCATION OF AREA 3 SEPTIC WASTE SYSTEMS 2 \& 6,

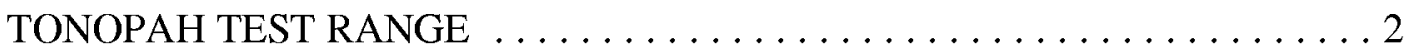

FIGURE 2 - CAU 427 TONOPAH TEST RANGE SEPTIC WASTE SYSTEMS 2 \& 6 . . . . 3 


\section{ACRONYMS AND ABBREVIATIONS}

BN Bechtel Nevada

CADD Corrective Action Decision Document

CAIP Corrective Action Investigation Plan

CAP Corrective Action Plan

CAS Corrective Action Site

CAU Corrective Action Unit

COC Constituents of Concern

CR Closure Report

DOE U.S. Department of Energy

DOE/NV U.S. Department of Energy, Nevada Operations Office

DQO Data Quality Objective

$\mathrm{ft} \quad$ feet

$\mathrm{ft}^{2} \quad$ square feet

gal gallon

$\mathrm{km} \quad$ kilometer

$1 \quad$ liter

$\mathrm{m}^{2} \quad$ square meter

$\mathrm{mg} / \mathrm{kg} \quad$ milligram per kilogram

mi mile

NAC Nevada Administrative Code 


\section{ACRONYMS AND ABBREVIATIONS (continued)}

NDEP Nevada Division of Environmental Protection

PAL Preliminary Action Level

RCRA Resources Conservation and Recovery Act

SNL Sandia National Laboratories

SWS Septic Waste System

TPH Total Petroleum Hydrocarbon

TTR Tonopah Test Range 


\section{ABSTRACT}

This Corrective Action Plan provides the closure methods for Corrective Action Unit 427: Area 3 Septic Waste Systems (SWS) 2 and 6, located at the Tonopah Test Range. SWS 2 consists of Septic Tanks 33-4, 33-5, 33-6, and two associated leachfields. SWS 6 consists of one associated leachfield. The Area 3 SWS $2 \& 6$ are also known as Corrective Actions Sites (CASs) 03-05-002SW02 and 03-05-002-SW06 respectively.

Site investigation activities were completed in February 1998 and are documented in the Corrective Action Decision Document (CADD) [Department of Energy (DOE, 1998a)]. The site characterization found septage in Septic Tank 33-5. Septic Tank 33-4 is closed. Septic Tank 33-6 is still active and in line with the Sandia National Laboratories (SNL) consolidated system. This site was investigated for volatile organic compounds (VOC), semivolatile organic compounds (SVOC), polychlorinated biphenyls (PCBs), Resource Conservation \& Recovery Act (RCRA) metals, and total petroleum hydrocarbons (TPH). Characterization results of the three leachfields associated with these septic tanks were characterized and no PCBs, VOCs, SVOCs, or RCRA metals were detected above the Preliminary Action Levels (PALs). Arsenic was detected above PALs, but was deemed to be associated with natural elevated background concentrations in the area. Samples were also analyzed using gamma spectroscopy.

PALs were agreed upon with the Nevada Department of Environmental Protection during the characterization data quality objectives process and are outlined in the Corrective Action Investigation Plan (DOE, 1997a). The Nevada Administrative Code (NAC) Action Level for TPHs of 100 milligrams per kilogram were exceeded in samples from SWS 2 from the 1965-1975 and post-1975 leachfields, and the outfall end of Septic Tank 33-4. Within the CADD [Department of Energy, Nevada Operations Office (DOE/NV), 1998], an (a) through (k) analysis was conducted (NAC 445A.227). Based upon this analysis the concentrations of TPH detected in the unit do not present a significant hazard to the environment or groundwater. Biological activity will likely result in reduced concentrations of petroleum hydrocarbons over time. Therefore, the leachfields will be also closed-in-place with administrative controls being implemented. Warning signs will be erected to restrict intrusive activity onto the leachfields.

During the characterization, it was determined that Septic Tank 33-5 had not been closed. Therefore, closure activities will consist of removal of the residual septage and closure-in-place. Septic Tank 33-5 will be closed by filling of the emptied tank with clean inert material (sand) and sealing the top with a concrete cap. 
This Corrective Action Plan (CAP) provides the selected corrective action alternative and proposes the closure methodology for Corrective Action Unit (CAU) No. 427: Area 3 Septic Waste Systems (SWSs) 2 and 6. The site is located on the Tonopah Test Range (TTR), in the Nellis Air Force Range Complex. It is approximately 225 kilometers (km) (140 miles [mi]) northwest of Las Vegas, Nevada (Figure 1).

The SWSs were installed to receive sanitary waste and industrial liquid wastes generated from site maintenance and other daily operations conducted at the Area 3 Compound (Department of Energy (DOE), 1996a). SWSs 2 \& 6 were in operation during different time intervals from 1960 through 1990. Process knowledge regarding the composition of the waste water is limited because disposal practices commonly associated with early operations are unknown (DOE, 1997a). Specific details of the installation of subsurface components and the composition and condition of the collection system network were previously unknown.

CAU 427 comprises two Corrective Action Sites (CASs), each an individual SWS; CAS numbers 03-05-002-SW02 and 03-05-002-SW06 correspond to SWSs $2 \&$ 6, respectively. The site characterization was completed in February 1998; specific characterization details and Preliminary Action Levels (PALs) are provided in the Corrective Action Decision Document (CADD) (DOE, 1998a). Pre-characterization activities suggested that SWSs 2 and 6 consisted of five separate leachfields. The first phase of the site characterization consisted of excavating ten trenches to define the extent of the five inactive leachfields. The trenching field investigation identified three leachfields, approximately 186 square meters $\left(\mathrm{m}^{2}\right)[\sim 2,001$ square feet (sq. ft.)] each; no evidence for the other two leachfields could be found. Soil samples were collected and analyzed from soil layers within the leachfields, each distribution box, and the forks of the three discovered leachfields (Figure 2).

Results from the 1998 characterization activities are documented in the Corrective Action Investigation Report (CAIP) for CAU 427: Area 3 Septic Waste Systems 2 \& 6, found in Appendix A of the Corrective Action Decision Document (CADD) For CAU 427: Area 3 Septic Waste Systems 2 and 6, Tonopah Test Range, Nevada (DOE, 1998a). Constituents of concern (COCs) were identified in the Data Quality Objective (DQO) process as listed in the CAIP (DOE, 1997a). The characterization environmental samples were evaluated against the PALs established in the CAIP DQOs. A summary of the characterization is presented below:

- $\quad$ All volatile organic compounds (VOCs) were below the PALs outlined in the CAIP (DOE, 1997a). 


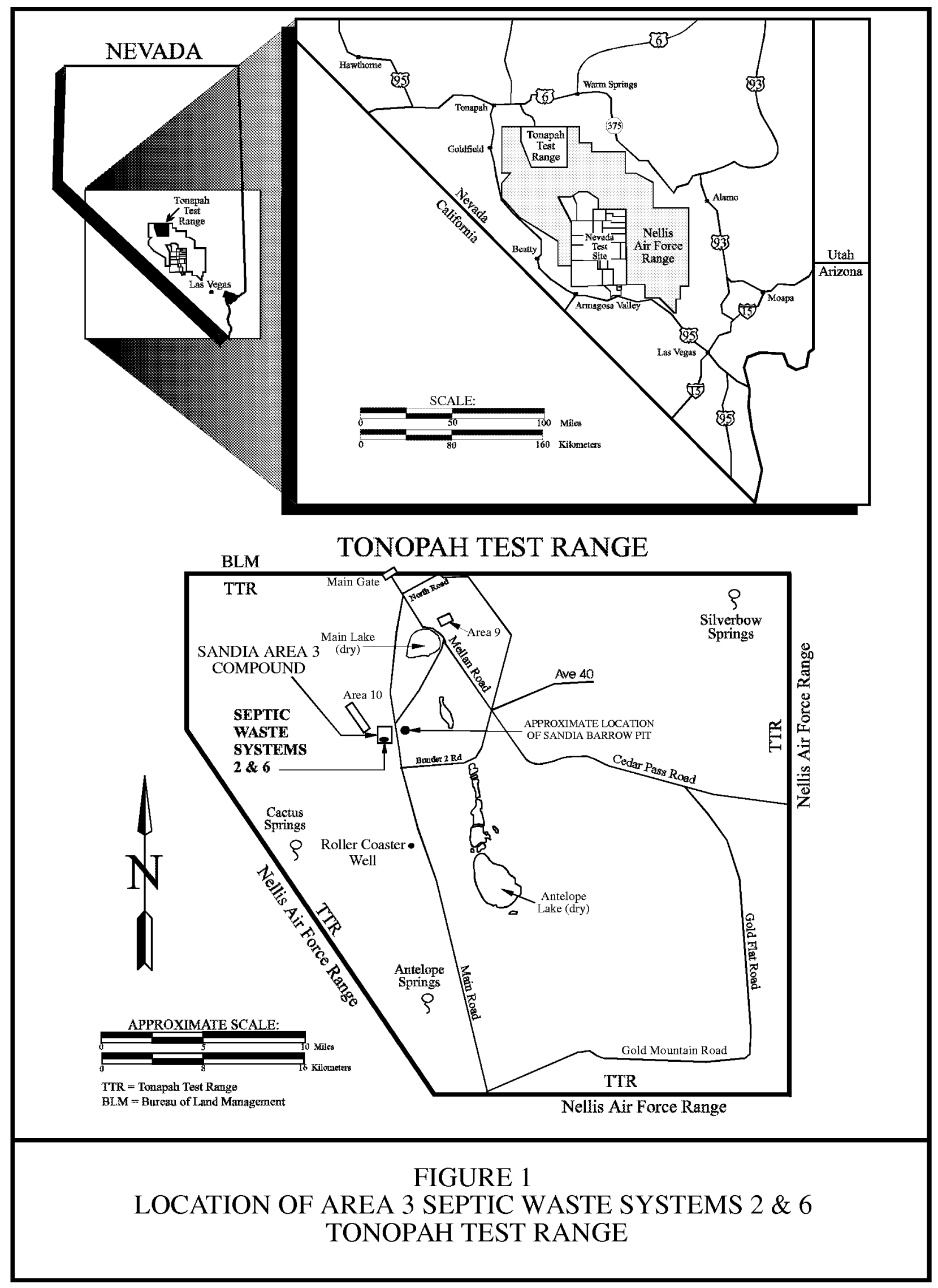




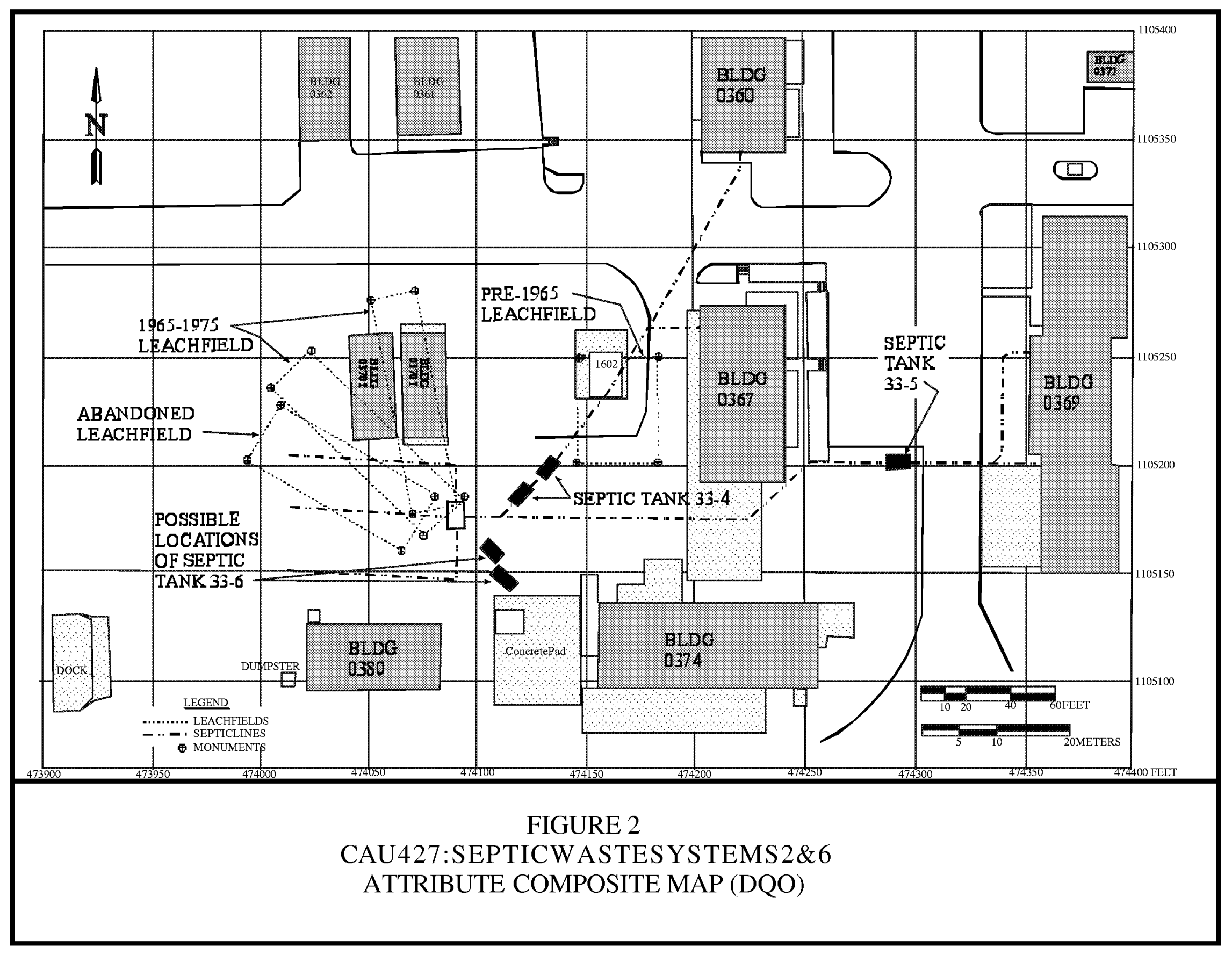


- All semivolatile organic compounds (SVOCs) were below the PALs outlined in the CAIP (DOE, 1997a). Pyrene was detected in a sample that also had a detectable level of petroleum hydrocarbons as waste oil, however it did not exceed the PAL of $100 \mathrm{mg} / \mathrm{kg}$ (CADD, 1998a).

- $\quad$ Fifteen of the 120 soil samples contained concentrations of petroleum hydrocarbons as waste oil at concentrations above the Nevada Administrative Code (NAC) action level of 100 milligrams/kilogram ( $\mathrm{mg} / \mathrm{kg}$ ). These concentrations are associated with the northern and central distribution lines and the distribution box of the Post-1975 Leachfield, the southeastern end of the 1965-1975 Leachfield, and the outfall end of Septic Tank 33-4 (Figure 2).

- $\quad$ Reported levels for all Resource Conservation and Recovery Act (RCRA) metal samples (arsenic, barium, cadmium, chromium, lead, mercury, selenium, and silver) were within the PALs established in the CAIP (DOE, 1997a) except for arsenic. The arsenic results were consistent with naturally occurring background levels as established in the corrective action investigation of CAU 424 Area 3 Landfill. The maximum arsenic concentration of $25.2 \mathrm{mg} / \mathrm{kg}$ was detected at 3.8 meters $(\mathrm{m})$ [ $12.5 \mathrm{feet}(\mathrm{ft})]$ in an area where fill material had been placed and is not believed to be associated with leachfield operations.

- $\quad$ No polychlorinated biphenyls (PCBs) were detected above the minimum reporting limits specified in the CAIP (DOE, 1997a).

- $\quad$ Radiological results are within PALs as established in the CAIP (DOE, 1997a) with the exception of three potassium-40 results. These samples were reanalyzed and found to be within PALs.

- $\quad$ Septic Tanks 33-4 and 33-5 found during the characterization investigation were inactive. However, Septic Tank 33-6 is active. Although inactive, Septic Tank 33-5 contained septage. Septage within Septic Tank 33-5 has been sampled and the results were assessed by Bechtel Nevada (BN). Reported levels of hazardous constituents were significantly lower than RCRA-established levels for non-waste water and waste water treatment and disposal requirements. Soil samples were obtained from the outfall end of Septic Tank 335 , and their associated analytical results did not indicate that a release had occurred. 


\subsection{PURPOSE}

The purpose of this CAP is to provide the methods for implementing the recommended corrective action alternative 2 in the CADD (DOE, 1998a). Detailed information of the site history and results of the previous characterization activities are found in the CADD (DOE, 1998).

\subsection{SCOPE}

The scope of this plan is to provide the methods for in-place closure of Septic Tank 33-5 and administrative controls of CAU 427. Based on the findings of the previous investigation, the selected corrective action alternative is:

- Closure in-place of Septic Tank 33-5 by removing all septage waste and filling the tank with clean sand and sealing it with cement.

- Administrative controls - Posting signs and implementing use restrictions to prevent intrusive activities.

\subsection{CORRECTIVE ACTION PLAN CONTENTS}

This CAP is divided into the following sections:

- Section 1.0 - Introduction: Summary of previous work and presents the purpose and scope.

- Section 2.0 - Detailed Statement of Work: Approved corrective alternative implementation methodology, construction quality assurance, and waste management.

- Section 3.0 - Schedule.

- Section 4.0 - Post-Closure Monitoring Plan.

- $\quad$ Section 5.0 - References.

- Appendix B - Project Organization

- Appendix C - Distribution List. 
This plan was developed using information and guidance provided from the following documents:

- Corrective Action Investigation Plan for CAU 427: Area 3 Septic Waste Systems 2 and 6, Rev. 0, DOE, June 1997

- Corrective Action Decision Document for CAU 427: Area 3 Septic Waste Systems 2 and 6, Rev. 0, July 1997, DOE, April 1998, DOE/NV-429

- Nevada Environmental Restoration Project, Project Management Plan, Revision 0, DOE, 1994.

- Nevada Environmental Restoration Project. Health and Safety Plan, Revision 2, DOE, 1996.

- Nevada Environmental Restoration Project, Industrial Waste Sites, Quality Assurance Project Plan, Nevada Test Site, Revision 1, DOE, 1996. 


\subsection{DETAILED STATEMENT OF WORK}

\subsection{APPROVED ALTERNATIVE IMPLEMENTATION}

The objectives of the corrective action alternatives selected in the CADD (DOE, 1998a) are to prevent or mitigate human exposure to subsurface soils containing waste, close Septic Tank 33-5 following NAC 459 (NAC, 1996c), and prevent adverse impacts to groundwater.

The Final CADD was approved by NDEP on June 24, 1998. The selected alternative is closure in-place of Septic Tank 33-5 and establishing administrative controls over the septic system piping and leachfields. Closure activities are anticipated to consist of the following activities:

- Removal of remaining septage from Septic Tank 33-5 into B-25 boxes for disposal.

- In-place closure of Septic Tank 33-5 by filling the tank with an inert material following NAC 459 (NAC, 1996a).

- Administrative controls - Posting signs and implementing use restrictions to prevent intrusive activity.

Coordination of the closure will include the U.S. Air Force because of the location of the site and land-use status. The future use of any land related to this CAU will be restricted from activities that may alter or modify the containment control as identified in the Closure Report (CR) unless appropriate concurrence is obtained in advance.

\subsubsection{Removal of Septage from Septic Tank 33-5}

The residual septage in Septic Tank 33-5 will be excavated by a backhoe and packaged as nonhazardous waste. Removed septage will be placed into overpack 322-liter (1) [ 85-gallon (gal)] drums and transported to the appropriate landfill. Waste will be shipped and labeled with the appropriate documentation.

Standard construction equipment will be used for excavation and closure activities. Equipment will consist of, but will not be limited to: backhoe, front end loader, septage pump truck, and end and/or belly dump trucks.

Environmental monitoring or decontamination of site equipment is not proposed during the closure activities, as hazardous or radiological constituents were not found which exceeded action levels during the 1998 characterization activities. 


\subsubsection{Closure In-Place Of Septic Tank 33-5}

Septic Tank 33-5 will be closed in-place by first removing the septage by backhoe and containerizing the waste as outlined in Section 2.1.1. The septic tank will then be filled with a clean inert material (sand), in accordance with NAC 459 (NAC, 1996c), and then sealed with cement.

Samples taken of the septage in Septic Tank 33-5 indicate the presence of listed hazardous waste. The analytical data from the characterization of the septage was assessed against RCRA criteria for hazardous waste constituents. Results indicate that RCRA listed hazardous wastes found are significantly below non-waste water and waste water treatment standards and disposal requirements. Due to historical and process knowledge, the septage will be treated and disposed of as nonhazardous waste in an appropriate landfill.

\subsubsection{Administrative Controls - Posting Of Warning Signs}

Permanent warning signs will be posted locating and/or delineating specific SWSs 2 \& 6 components and the boundary corners of each leachfield. Signs will have the following information:

- $\quad$ Leachfield identification (for example, "CAU 427, boundary of sewage leachfield).

- Warning (for example, "Warning, Buried Leachfield and Contaminated Soil").

- Instructions (for example, "Contact [office] at [phone no.] before digging, trenching, or removing this sign").

In addition, a detailed site 'as built' figure will be on file with the Sandia National Laboratories Field Office and their Maintenance and Operations contractor. The TTR is a restricted area, with security measures already in place 24 hours a day, 365 days a year, which will limit the access to the site.

\subsection{CONSTRUCTION QUALITY ASSURANCE}

Construction activities consist primarily of excavation and posting of signs; therefore, no construction quality assurance is required. 


\subsection{WASTE MANAGEMENT}

Hazardous and radioactive wastes are not anticipated to be generated as a result of following this plan. Soil containing petroleum hydrocarbons will be closed in-place as approved by the NDEP.

Initial waste characterization of the septage from Septic Tank 33-5 indicated the presence of listed hazardous waste. The results were assessed by $\mathrm{BN}$ and found to contain levels of hazardous waste significantly below the non-waste water treatment standards. Due to adequately low levels and process knowledge, the septage will be handled as nonhazardous waste and be disposed of in the appropriate landfill.

Any other waste generated at the site is anticipated to be non-hazardous construction debris associated with the closure of Septic Tank 33-5 (paper, plastic, wood, metal) and personal protective equipment. The construction debris and personal protective equipment will be transported to and disposed of in either a TTR- or Nevada Test Site-permitted landfill according to DOE orders, Department of Transportation requirements, state and federal, agreements, and permits between the DOE/NV and NDEP. 
The DOE/NV requires field activities to be completed by December 31, 1998. The following is the anticipated activities and schedule:

- Begin coordination of field closure activities within 60 days of receiving final CAP approval from the NDEP.

- Complete field closure (removal of septage, filling of septic tank, posting of signs, and administrative controls) within 60 days after beginning field closure activities. Some minor activities such as sign installation and removal/disposal of construction debris may occur after field activities are completed.

- Prepare the CR for submittal to NDEP within approximately 120 days after completion of the closure.

Flexibility has been placed in the project schedule to account for minor difficulties (weather, equipment breakdowns, etc.). The DOE will keep the NDEP apprised of any condition that may impact the project schedule. 


\subsection{POST-CLOSURE MONITORING PLAN}

The proposed monitoring consists of annual (yearly) visual inspection of the signs to verify that signs are in-place, readable, and that use restrictions are maintained. Nonscheduled inspections are not required after severe weather events such as heavy rainfall, flash floods, and high winds, because the waste is buried in the subsurface. Any identified maintenance and repair requirements will be completed within 90 days of discovery and documented in writing at the time of repair.

Specific details for the Post-Closure Monitoring Plan will be proposed in the CR. 


\subsection{REFERENCES}

CFR, see Code of Federal Regulations.

Code of Federal Regulations, 1998, Title 40 CFR Parts 260-281, RCRA Regulations.

Washington, D.C.

DOE/NV, see U.S. Department of Energy, Nevada Operations Office.

DOE/NV, 1998, Corrective Action Decision Document for CAU 427: Area 3 Septic Systems 2 $\underline{\&}$, Rev. 1, April 1998, DOE/NV-474.

DOE/NV, 1998, Corrective Action Investigation Plan for CAU 427: Area 3 Septic Waste Systems $2 \& 6$, Rev. 0, June 1998, DOE/NV-429.

DOE/NV, 1998, Nevada Environmental Restoration Project. Health and Safety Plan, Rev. 2, DOE/NV, 1996

EPA, see U.S. Environmental Protection Agency

EPA, 1996, Region IX Preliminary Remediation Goals (PRGs), San Francisco, CA.

FFACO, see Federal Facility Agreement and Consent Order.

FFACO, 1996, Agreed to by the Nevada Division of Environmental Protection, the U.S. Department of Energy, and the U.S. Department of Defense.

NAC, see Nevada Administrative Code.

Nevada Administrative Code, 1996a, NAC 444, Solid Waste Disposal. Carson City, NV.

Nevada Administrative Code, 1996b, NAC 445A, Water Pollution Control. Carson City, NV.

Nevada Administrative Code, 1996c, NAC 459, Disposal and Evaluation of Contaminated

Soil. Carson City, NV.

NRS, see Nevada Revised Statutes.

Nevada Revised Statutes. 1995, NRS 459.400-459.600, Disposal of Hazardous Waste. 


\subsection{REFERENCES (continued)}

U.S. Department of Energy, Nevada Operations Office. 1994. Nevada Environmental Restoration Project, Project Management Plan, Rev. 0. Las Vegas, NV.

U.S. Department of Energy, Nevada Operations Office. 1996a. Corrective Action Unit Work Plan, Tonopah Test Range, Nevada, DOE/NV--426. Las Vegas, NV.

U.S. Department of Energy, Nevada Operations Office. 1996b. Final Environmental Impact Statement for the Nevada Test Site and Off-site Locations in the State of Nevada, Volume I, DOE/EIS 0243. Las Vegas, NV.

U.S. Department of Energy, Nevada Operations Office. 1996c. Industrial Waste Quality Assurance Project Plan, DOE/NV--425. Las Vegas, NV.

U.S. Department of Energy, Nevada Operation Office. 1997a. Corrective Action Investigation Plan for Corrective Action Unit No. 427: Area 3 Septic Waste System Numbers 2 and 6, Tonopah Test Range, Nevada, Rev. 0. Las Vegas, NV.

U.S. Environmental Protection Agency, Office of Solid Waste and Emergency Response. 1994. Final RCRA Corrective Action Plan, EPA/520-R-94-004. Washington, D.C. 


\section{APPENDIX A}

\section{PROJECT ORGANIZATION}


The following are the DOE/NV project contacts:

Runore C. Wycoff

Project Manager

Nevada Environmental Restoration Project

U.S. Department of Energy, Nevada Operations Office

P.O. Box 98518

Las Vegas, NV, 89193-8518

(702) 295-2011

Janet L. Appenzeller-Wing

Subproject Manager

Industrial Sites Subproject

U.S. Department of Energy, Nevada Operations Office

P.O. Box 98518

Las Vegas, NV, 89193-8518

(702) 295-0461

The identification of the project Health and Safety Officer and the Quality Assurance Officer can be found in the DOE plan. However, personnel are subject to change and it is suggested that the Project Manager be contacted for further information. The Task Manager will be identified in the FFACO Biweekly Activity Report prior to the start of field activities. 


\section{APPENDIX B}

\section{DISTRIBUTION LIST}




\section{DISTRIBUTION LIST}

$\underline{\text { Copies }}$

Division of Environmental Protection

Bureau of Federal Facilities

333 W. Nye Lane, Room 13B

Carson City, NV, 89706-0866

Paul Liebendorfer

Supervisor, Las Vegas Office

555 E. Washington, Suite 4300

Las Vegas, NV, 89010

U. S. Department of Energy, Nevada Operations Office

P. O. Box 98518

Las Vegas, NV 89193-8518

J. L. Appenzeller-Wing

1

K. J. Cabble

Public Reading Facility

Technical Information Resource Center

U. S. Department of Energy, Office of Scientific and Technical Information

175 Oak Ridge Turnpike

P. O. Box 62

Oak Ridge, TN 37831-0062

\section{Bechtel Nevada}

P. O. Box 98521, M/S NLV 008

Las Vegas, NV 89193-8521

D. K. Cowser

A. M. Heidema

S. J. Nacht

J. L. Smith

J. G. Nelson 


\section{DISTRIBUTION LIST (continued)}

$\underline{\text { Copies }}$

IT Corporation

P.O. Box 93838

Las Vegas, NV 89193

K. C. Beach

M. Todd 